研究発表論文

\title{
戦前期熊本の都市形成事業における風致地区の位置付け \\ The Position of Scenic Areas in the City Planning of Kumamoto City
}

\author{
真田 純子* 本田 百合絵** 田中 尚人*** \\ Junko SANADA Yurie HONDA Naoto TANAKA
}

\begin{abstract}
This study aimed at clarifying the position of scenic areas of Kumamoto city planning before WWII. This study got a clue about the position of scenic areas from its explanations. In explanations there are words as "to make park for Kumamoto citizen" and "suitable for suburban residential district". So this study start from the hypothesis that the scenic areas were the plan for whole of Kumamoto citizen, not the plan closed in its own areas. To clarify the position of, this study focused on the following three points; 1) how were expected the scenic areas when its plan was make. 2) how kind of relationship were there between the scenic areas and the other city planning projects, in the view of sites and the each project's aim. 3) how ware transformed the scenic areas and its periphery, peculiarly works for parks and land readjustment. Through the researches above, it can say that each city forming projects; street planning, the union of Kumamoto City and peripheral towns and land readjustments ware made under an idea that quality residential areas had better be built in scenic suburban area.
\end{abstract}

Keywords: scenic area, suburb, land readjustment, suburban park キーワード：風致地区, 郊外, 区画整理, 郊外公園

\section{1. はじめに}

\section{(1) 研究の背景および目的}

熊本都市計画区域では、六大都市以外で最も早く 1930 年に風致 地区が指定された。風致地区指定の翌 1931 年には、内務省都市計 画課の技師であった北村徳太郎が熊本市内の公園設計のために熊 本を訪れ、そのときに見た江津湖の美しさに惹かれその価值を永 久に保全するため「熊本市郊外江津湖を中心とする敷地計畫殊に 其の公園系統について ${ }^{11} 」 を$ 発案し「都市公論」誌上で発表した。 案の中で、水前寺駅前を中心とした集落を形成し「好個の熊本市 郊外住宅地」とすること、また江津湖を公園として「大熊本市民 の都市公園」とすることを提案している。つまり、単に江津湖と その周辺だけを見ていたのではなく、熊本都市圏のなかでの位置 づけを考えていたと言える。

北村の提案が、どれほど当時の熊本都市計画の理念を汲んだも のであったかは不明であるが、実際、風致地区指定時にまとめら れた「沿革及現況」をみてみると、江津湖地区以外の風致地区で も、「熊本北方の住宅地として発達」や「熊本市民の森林公園」な どの言葉が見られ 2)、風致地区がそれ単体としてだけではなく、 都市全体の計画の中で役割を持っていたと推察される。

こうした状況を踏まえ、本研究では戦前期の熊本都市形成にお いて、風致地区がどのような位置づけで考えられていたのかを明 らかにすることを目的とする。

そのために本研究では、以下の3 点に着目する。

1）風致地区そのものにかけられていた期待

2）風致地区の配置と他の都市整備・都市計画事業との関係

3）風致地区とその周辺が指定後にどう整備されたか

なお2）3）については、都市を形成していくという意思のな かでの風致地区の位置づけを見るため、行政の行う市町村合併や 都市計画事業を「整備」の内容とする。また $3 ）$ の「指定後」の 時期は、時代や制度が大きく変化する前までで、具体的には都市 計画法の目的に防空が加わり、施設に緑地が加えられる以前の
1939 年までとした。

本研究では、都市計画資料および都市計画図、新聞記事、「都市 公論」などの雑誌、観光用冊子、小学校の百周年記念誌、古写真 などを用いた。

\section{(2) 研究の位置づけ}

戦前の風致地区に関する既往研究は、当時の風致地区の概念設

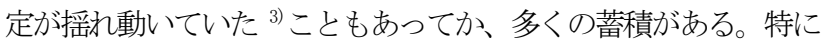
風致概念の意味に着目寸るもの ${ }^{4}$ や風致地区制度の変遷や意義を 問うもの ${ }^{5}$ が多い。しかしこれらは風致地区そのものや風致地区 制度そのものを扱っており、他の都市計画事業との関連にはあま り着目していない。個別の都市における風致地区を扱った研究に は、東京、京都、足利、熊本についての研究がある。東京の風致 地区を扱った皆方の研究 ${ }^{6}$ では、風致地区の目的となっていた近 郊行楽地としての整備や良好な住宅地形成に言及しているが、研 究の主眼は風致協会の果たした役割にあり、公的な都市計画のな かでの風致地区の位置付けに着目したものではない。京都を扱っ た中林の研究 7)では、京都の風致地区が市街地から見えること、 縁となる山の市街化を食い止めるため、と都市全体との関連に言 及しているが、他の都市計画事業との関わりについては述べてい ない。京都の風致地区に関寸るその他の研究も、風致地区そのも のに着目している。足利の風致地区に関する福島らの研究 ${ }^{8)}$ では、 結論において風致地区を「近隣地域および地域住民の慰楽・保健 衛生を目的とした地区」と、都市全体を視野に入れて位置付けて いるが、その根拠は、近隣から訪れるような名所・旧跡が風致地 区に選ばれたからということであり、都市計画のなかでの位置づ けとしては分析されていない。熊本の風致地区を扱った阿部の研 究 ${ }^{9)}$ では市街地の拡大と風致地区の公園整備の関係を明らかにし ているが、現象として起こった市街地の拡大を扱っている。この 点で都市形成事業に見られる意図と風致地区との関係を扱った本 研究とは異なる。

熊本の風致地区のひとつである江津湖を扱った本田らの研究 ${ }^{10)}$

\footnotetext{
*徳島大学工学部、*株式会社オオバ **熊本大学政策創造研究教育センター
} 
では、後に公園化された江津湖風致地区が、都市計画区域設定の 段階から公園化を目的としたものであったといい、都市計画と風 致地区の関連性について述べているが、その他の都市計画事業や 江津湖以外の風致地区の位置付けについては触れていない。

その他、複数の都市における風致地区を扱った研究として、野 中の研究 ${ }^{11}$ がある。城下町都市を対象にして城下町基盤との位置 的関係に主眼を置いた研究である。他の都市計画事業である街路 計画や地域計画等についてはその計画決定順序について触れてい るのみである。また風致地区の指定意図を強化するものとしての 太政官公園、都市計画公園、史跡名勝天然記念物指定との重層性 についてまとめている。したがって、たとえば街路計画と風致地 区をどのように結びつけようとしたかなど、都市を形成しようと する戦前期の諸計画のなかで風致地区がごのような位置づけにあ ったものかを明らかにしようとする本研究とは異なると言える。

以上の上うに、風致地区を扱った研究は多いが、同時代の他の 都市計画事業との関係に着目し、風致地区の都市形成上の位置つ けについて明らかにした研究はなされてこなかったと言える。

\section{2. 熊本都市計画風致地区にかけられていた期待}

本章では、当初の風致地区にかけられていた期待を理解するた めに、熊本の都市計画における風致地区の概要を整理した後、風 致地区指定の際にまとめられた各地区の「沿革及現況」から、指 定当時の状況や各風致地区に見られた展望について整理した。

\section{（1）風致地区の概要}

1930 年に熊本市郊外の 7 風致地区が、市街地を取り囲むように 指定された（図1)。1923 年に都市計画法適用都市に指定され、 1925 年に区域決定、1928 年に街路決定、市街地建築物法による地 域指定が行われた。その後、1930 年に風致地区の指定が行われた。

風致地区指定理由書によると、風致地区の指定は、市街地の膨 張に伴う景勝地の破壊を防ぐ目的 ${ }^{12}$ があるということである。ま た、風致を維持し市民の慰楽に備えることは「都市計画上重要」 であることも記載されている。

指定地区についての審議が行われた第五回都市計画熊本地方委 員会では、都市計画技師であった吉田次郎が説明にあたった。彼 は「従来維持セラレテイル箇所ヤ、将来開発ノ盧レナキ箇所八、

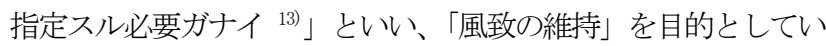
ると説明している。

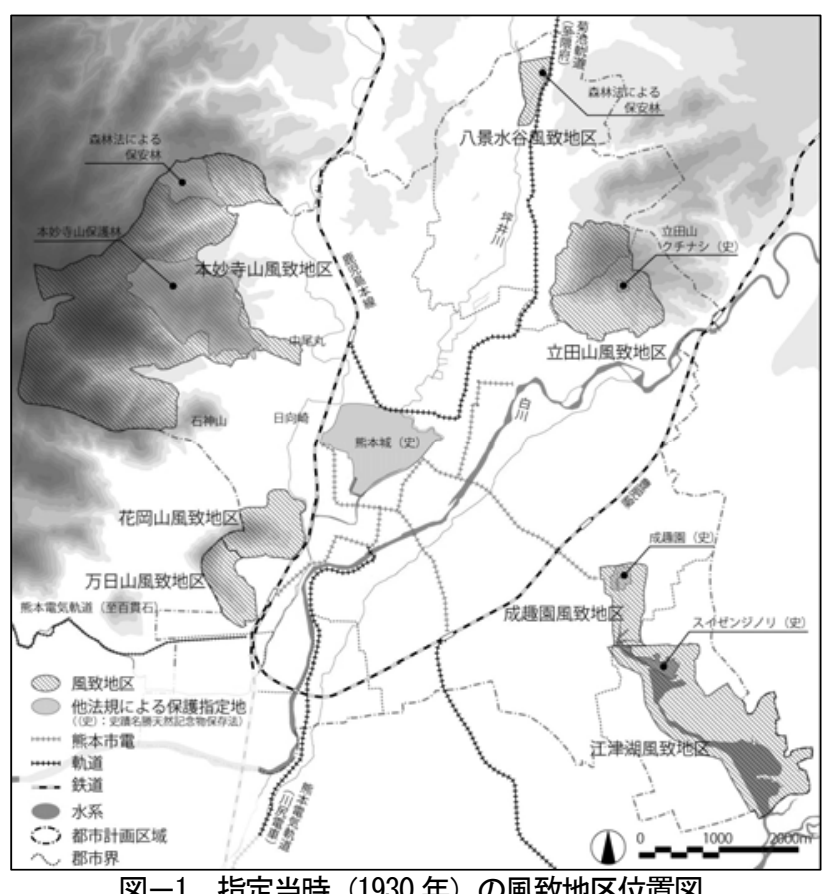

図-1 指定当時（1930 年）の風致地区位置図

\section{（2）各風致地区の状況および展望}

1）個別説明の整理方法

上記の説明は法定都市計画として成立させるための風致地区の 説明である。ここでは、実際にどのような土地が指定されていた のかを把握寸るため、「沿革及現況」の各地区の個別の説明から、 指定当時の状況や指定時の説明に見られる各地区の展望を整理し た (表 1 )。風致地区指定の際にまとめられた各地区の「沿革及現 況」は、1930 年に風致地区指定が審議された第 5 回都市計画熊本 地方委員会において委員に配付された資料である。

表の作成にあたっては、以下の手順で行った。まず、もともと どのような場所であったかを把握するために、「、. 歴史的価値」 についてと、そこが近世からの行楽地であったかどうかについて

(「b. 伝統的行楽地」) 着目した。続いて「c. 風景」がどのように 説明されているがついて着目した。また、各風致地区の都市の 中での位置関係に言及されているかを見るため「d. 市街地との関

\section{表-1 風致地区の個別の状況と展望}

\begin{tabular}{|c|c|c|c|c|c|}
\hline & \begin{tabular}{|l|} 
a. 歴史 \\
的洒値
\end{tabular} & $\begin{array}{l}\text { b. 伝統的 } \\
\text { 行楽地 }\end{array}$ & c. 風景 & d. 市街地との関係 & e. 今後の展望 \\
\hline 八景水谷 & 0 & 0 & 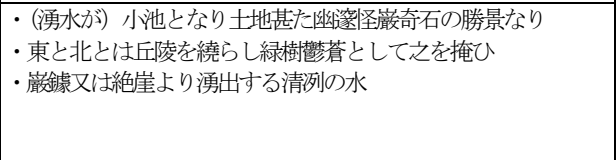 & $\begin{array}{l}\text { •熊本市街の北に接近して } \\
\cdot \text { 熊本市北郊第一の勝地たる }\end{array}$ & 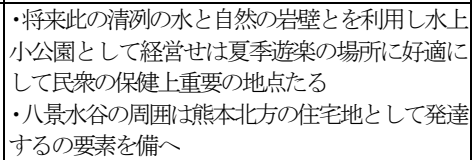 \\
\hline 立田山 & 0 & 0 & 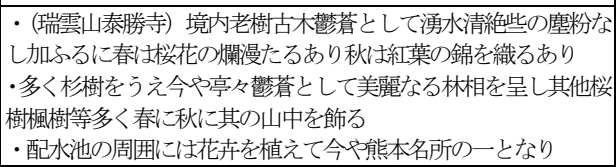 & \begin{tabular}{|l|}
$\cdot$ 熊本市東部の一勝地なり \\
·熊本市に近く峙つて古来市民の行楽 \\
地として愛したる山なり
\end{tabular} & 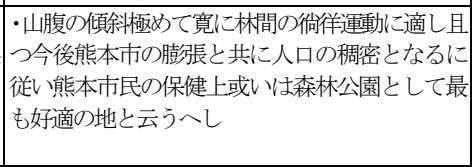 \\
\hline 成趣園 & 0 & O & $\begin{array}{l}\text { ·泉石の美を盡すのみならす春は花を賞し夏は涼を納るへく秋は } \\
\text { 付きを愛て冬は雪の眺めあり }\end{array}$ & ・市電の便を有し市民唯一の行楽地 & $\begin{array}{l}\text { ·熊本の有する誇りの名園なり然して本園は市民 } \\
\text { の健康增進上、行楽慰上、将た本市の発展上実 } \\
\text { に必要欠くへからさる地なり }\end{array}$ \\
\hline 江津湖 & O & - & \begin{tabular}{|l|l}
-春夏の侯船を砂取に貸して楊柳水面を搤するの間清凉に興して \\
湖に絶景を賞せむ
\end{tabular} & $\begin{array}{l}\cdot \text { •この湖は実に熊本市附近の一勝地に } \\
\text { して } \\
\text { ・本湖は熊本市に近く（中略）納涼の } \\
\text { 好適地なり }\end{array}$ & $\begin{array}{l}\text { ·熊本の夏は九州他都市に比して暑熱烈しと称せ } \\
\text { らるを以て他日之に施設を加へ水上公園として } \\
\text { 経営せは市民の保健上、慰安上舟遊水泳場として } \\
\text { 納涼の好適地なり }\end{array}$ \\
\hline 花岡山 & 0 & 0 & 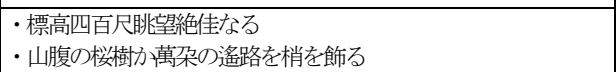 & - & $\begin{array}{l}\text { (万日山の説明に） } \\
\text { ·花岡山と共に熊本市民の登山遊息の地なり市民 }\end{array}$ \\
\hline 万日山 & 0 & 0 & 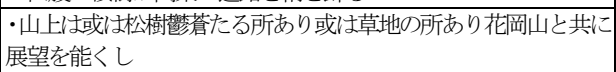 & ・熊本市近郊の一勝地たる & \begin{tabular}{|l|} 
の保健健康上之に相当の施設を為すの急務なる \\
废す
\end{tabular} \\
\hline 本妙寺山 & 0 & - & 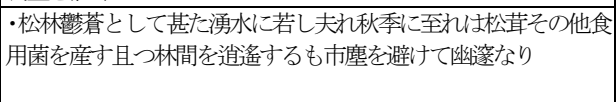 & \begin{tabular}{|l} 
·熊本駅を距る西南約四五丁の一丘嶺 \\
・河内往還開通せしを以て交通甚た利 \\
便となり
\end{tabular} & $\begin{array}{l}\text { ·立田山と共に本山中を利用して森林公園とも為 } \\
\text { さは市民の保健上利益大なるへし } \\
\text { •山下各地は住宅地として好適 }\end{array}$ \\
\hline
\end{tabular}


係」に関する記述に着目した。また最後に、各風致地区をどうし ていくべきかという「e. 今後の展望」への言及に着目した。

2）個別説明から見る風致地区の位置付け

個別の説明を上記の着眼点に従って整理した結果、歴史的価値 としてはいずれも加藤清正や藩主細川家との関わりのある場所で あることがわかった。また、歷史的価値に関連して、古くからの 行楽地として親しまれているということも、江津湖と本妙寺以外 の風致地区で書かれていた。なお本妙寺は行楽地との説明はない が、本妙寺および浄池廟を参詣する人々が「四時昼夜群参跡を絶

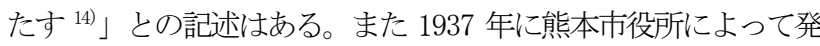

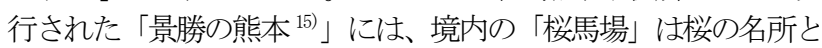
して知られているとあり、実質的には近世から行楽地として親し まれていたと考えられる。また江津湖こついては 1932 年の画津村 合併時の行政資料に「特に盛夏の候、(中略) 水遊寸る地方民乃至 外来客は数万に上り、地方唯一の歓楽境をを現出する状況にある のみならす、其の誘客は毎年激増し、殷賑は倍加し、今や夏季に

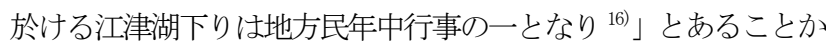
ら、近世からの伝統的な行楽地ではなかったものの、風致地区に 指定された 1930 年の段階では新興の行楽地として認知されてい たと考えられる。

風致地区の風景に関しては、すべての風致地区において風景が 良いことが書かれ、具体的には樹木が㯊蒼としているところ、湧 水があるところなどの自然的要素に加え、桜や楓など季節ごとの 楽しみのある場所だと書かれている。また花岡山や万日山では朓 望の良さが記述されている。続いて、こうした風景の良い行楽地 と市街地との関係について見てみると、7つの風致地区のうち、 5 地区で「熊本市近郊の一勝地」などの記述があり、「近郊」であ ることが意識されていたことがうかがえる。

またこれらの風致地区をその後どう整備していくかという展望

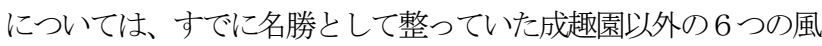
致地区すべてにおいて施設を整えて市民の保健に役立てるべきで あると書かれている。その場所の風致が存在することといらより は、熊本市民がそこに行くことによって生まれる「市民の保健」 という価値を重視しているといえる。八景水谷、本妙寺山では、 周囲あるいは一部を住宅地とすることも提案されている。

\section{（3）風致地区にかけられていた期待}

以上の結果より、風致地区はもともと風景の良い、熊本近郊の 行楽地、あるいはその自然環境を楽しみに行くような場所が選ば れていたことがわかる。また将来的には手を加えて公園や住宅地 にすることを目論んでいたことがうかがえる。景勝地の破壊を防 ぐという保全ではなく、すでに良い環境のところを指定し、そこ に手を加えながら利用することが前提となっていた。戦前期の熊 本都市計画では都市計画公園や都市計画緑地は計画されていない が、風致地区にそのような機能を期待していたといえる。風致地 区で想定されていた公園的な利用に関しては、その周囲の住民用 というよりは、熊本市民のためという位置づけであった。都市近 郊の良好な環境を享受できる場所、というのが風致地区にかけら れていた期待であると考えられる。

\section{3．都市整備・他の都市計画事業との関係}

本章では、都市の発展過程を整理し、風致地区との関連を見て いく。（1）では風致地区指定前後に行われた熊本市の町村合併、 （2）では交通機関との関係、(3) では土地区画整理との関係を みることで、風致地区との位置関係やその説明から都市全体の計 画と風致地区がごのような関係にあったのかを明らかにする。

\section{（1）市域面積の拡大}

熊本市は、市制を施行した 1889 年以降、町村合併によりその面 積を拡大していった（図2)。1925 年に都市計画区域を決定した

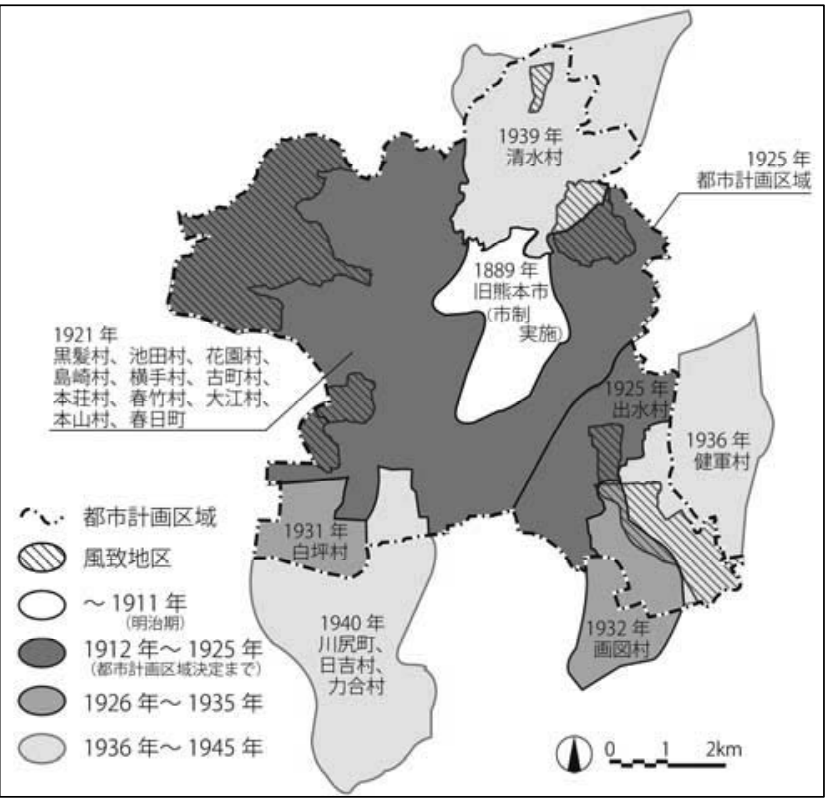

図一2 市域面積の拡大過程

段階では、中心市となる熊本市以外に、白坪村、および、画津村、 健軍村、清水村、日吉村の各一部を含んだ形となっていた。

都市計画区域について話し合われた第二回都市計画熊本地方委 員会に先だって熊本市および周囲の 5 村に照会したところ、清水 村、健軍村、画津村から委員会の提案する都市計画区域に異存は なかったが、全村域を都市計画区域にするよう希望があった。第 二回委員会での説明によれば、都市計画区域の決定は「都市の有 機的機能を発揮せしむる」ため、交通機関が発達した際に商業的 中枢点まで 30〜40 分で到達できる範囲の 4 マイルの円をまとま りある都市と想定し、そこに天然の地形や行政区画を考慮した、 ということである。その結果「北は清水村の一部東南は画津村健 軍村の一部西南は白坪村日吉村の一部と云うことになるのであり ます」と説明された ${ }^{17)}$

つまり、後に行われる合併とは関係なく都市機能の観点から都 市計画区域を決定したと考えられる。つづいて合併の理由につい て考察してみると「新熊本市史」に収められた合併時の市政資料 によれば、1931 年の白坪村の合併までは、「市の周囲に於て市街 地を為せる町村」の合併であったとの記述 ${ }^{18}$ )があり、熊本市と一 連の市街地と見なされる地域を市域に編入したとの説明である。

つぎの合併は、1932 年の江津湖風致地区を有寸る画津村である。 江津湖風致地区は、風致地区指定時に「他日之に施設を加え水上 公園として経営せは市民の保健上、慰安上舟遊水泳場として納涼 の好適地なり」と説明されていた、「公園化」が目論まれた風致地 区であった。合併時の資料には「連担戸数少なき為」合併の機運 は高まらなかったとあり ${ }^{19}$ 、それまでの合併とは理由が異なるこ とが分かる。同資料で、画津村にある江津湖は、既に市域に含ま れている「天下の名勝たる水前寺」と相互補完関係にあるとされ、 これを公園化することは「市村民の福利増進に寄与貢献すること の大なるは敢て疑の余地なき ${ }^{20} 」$ と説明されている。また合併の 建議書には、江津湖が十八万市民の夏期の行楽場であるため「衛 生都市熊本」のために重要であると述べられている。風致地区指 定時に説明されたのと同様に、江津湖風致地区が熊本という都市 圈にとって重要な行楽地といら位置づけであることが分かる。

また、画津村からみた合併の理由としては、「現在戸数五百戸未 満にして、江津湖に対する施設は元より、土木・教育・勧業其の 他の諸般の施設経営は、将来独力を以て遂行寸るは甚だ困難に属 すへく(中略) 江津湖の関係上熊本市に併合するを最も有利と認 め...21)」とある。すでに都市計画区域には入っていたが、当時の 
都市計画事業は市町村がそれぞれ実施することになっていたため 村が単独で行うのは難しく、当初の目的である公園化を実現する ためには合併するのが適切であると考えられた、ということであ る。熊本市民のための風致地区を公園として整備するための合併 であったといえる。

つづいて 1936 年に健軍村が合併された。この合併の理由などは 資料が残っていないが、江津湖風致地区の大部分は健軍村に属し ており、江津村と同様の理由で合併した可能性は高い。

1939 年には、清水村が合併した。ここには、八景水谷風致地区 があるが、同風致地区には湧水があり、風致地区指定時の説明に よれば、施設を整えることで「清洌の水と自然の岩壁とを利用し 水上の小公園」にすることが目論まれ、また熊本北方の住宅地と して発達する要素を備えていると考えられていた場所である。清 水村の合併についても理由の書かれた行政資料は見あたらない。 しかし、当時の新聞 ${ }^{22)}$ の記事で紹介された合併祝賀会の熊本市長 の挨拶では、清水村に熊本市の水源池や配水池があることが触れ られ、市会副議長の祝辞では「天下晴れて熊本市の水として頂け るわけでこの点から喜びに堪えない」とあり、このことが大きな 理由であったと推測できる。ただ、市長の挨拶には「水清く空澄 双建康住宅地として発展する事は火を見るより明らかだ」とある。 当時の都市計画思潮から判断寸れば、健康住宅地とは、密集した 市街地とは異なる郊外の住宅地と理解できる。合併の目的ではな かったものの、ここでも八景水谷風致地区が郊外の良好な住宅適 地として認識されていたことがうかがえる。

\section{(2) 交通網の拡張}

熊本都市圏で計画された交通網として、1928 年に第三回都市計 画熊本地方委員会で話し合われた都市計画街路 ${ }^{23}$ について見てみ る(図 3)。「都市構築の根幹」とするために、放射状と環状、お よびその補助線の 3 タイプによって構成したと説明されている。

放射状の路線は北に 3 系統、南に 4 系統あると説明され、その うち都市計画区域外の都邑との連絡のためであると説明されたの は2 系統で、八景水谷・立田山方面のもの (A) と、成趣園・江津 湖方面のもの (B) であった。上記の 7 系統には、それ以外にも都 市計画区域の境界線まで伸びる系統もあったが、それらには都邑 との連絡という意困の説明はない。

配置の意図まで読み取ることは難しいが、状況としては、八景 水谷、立田山、成趣園、江津湖の 4 風致地区は、熊本都市圈の単 なる周縁部ではなく、郊外のなかでも人々の意識が都市圈の外に 向く方向に計画されたと言える。

また、その他の本妙寺山、花岡山、万日山風致地区について見 てみると、本妙寺山風致地区は中心市街地から近いうえに、すで

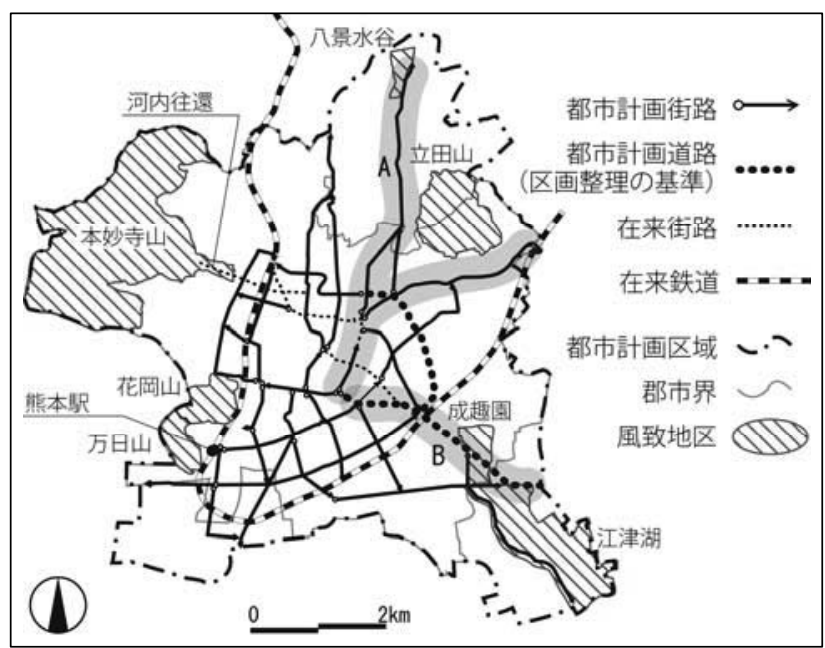

図-3 都市計画街路の配置
に中心市街地と河内往還によって結ばれていた。万日山、花岡山 風致地区は、熊本駅からほど近い場所にある。つまり、この3 風 致地区は上記の 4 地区に比べ比較的都心に近く、かつ既に交通の 便が良い場所であった。

また、補助線として計画された江津湖の西堤防の街路は「江津 湖をして遊覧地たらしむべく」計画されたと説明され ${ }^{24) 、 こ れ に ~}$ ついて、風致地区決定以前に郊外の風致利用を考えた街路計画 が作られていたといえる。

\section{(3) 住宅地の形成}

風致地区にかけられていた期待に、「住宅地化」があったため、 ここでは風致地区と住宅地の形成との関係を見る。都市計画とし てどこを住宅地化しようとしたかを見るために、都市計画事業の 土地区画整理に着目する。民間の住宅地開発ではなく都市計画事 業のみに着目する理由は、環境の良さに目をつけた民間の住宅地 開発は、熊本市や都市計画熊本地方委員会が考えていた熊本の都 市圈に対寸るビジョンとは異なる可能性があるからである。

また、熊本都市計画区域では風致地区決定以前の 1928 年に地域 計画も決められているが、市域の多くが住宅地域とされており、 用途地域の指定状況からは住宅地形成の意図を読み取ることがで きないため、土地区画整理に着目寸る。

1932 年に都市計画熊本地方委員会によって出された「熊本の都 市計畫」には、区画整理について「都市郊外地への無秩序なる膨 張を牽制して、整然たる街衢の出現を企するには、都市計畫法に 依る土地區劃整理事業に依るの外なし」と記載されている ${ }^{25)}$ 。ま た「熊本都市計畫概要」には、「本市の現況は人口に於て年々相當 の自然增加をな寸程度にて急に激增寸る傾向なきも逐次併合する 郊外地を漸次整理し將來の發展に備ふるを認め縣市協力して土地 區劃整理事業を勸獎せり」とも記載されている ${ }^{26)}$ 。つまり「無秩 序なる膨張」以外の方法で郊外を発展させていくために、土地区 画整理事業を用いようとの考えがあったことが分かる。1928 年の 街路計画策定時には、区画整理の基淮となる街路がいくつか計画 されていたが、そのうち用途地域が住居地域にあるものは、図3 の太い点線で示したもので、市の南東部に向かう街路であった。

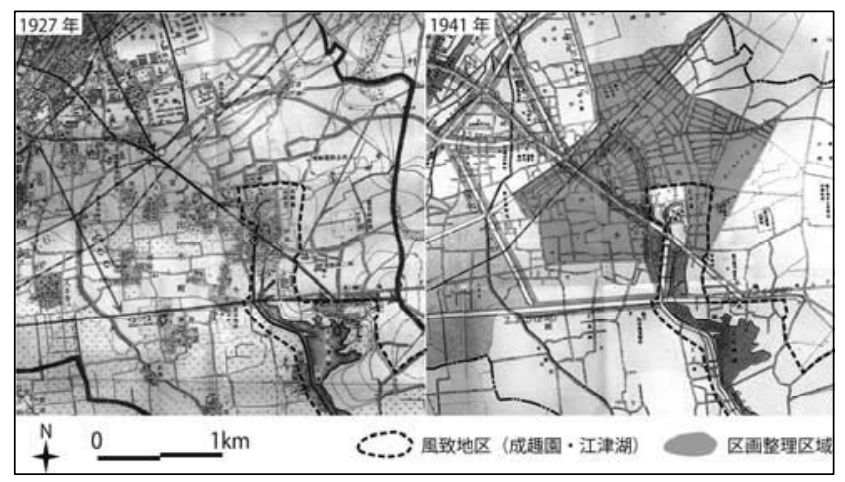

図-4 成趣園、江津湖風致地区付近の区画整理

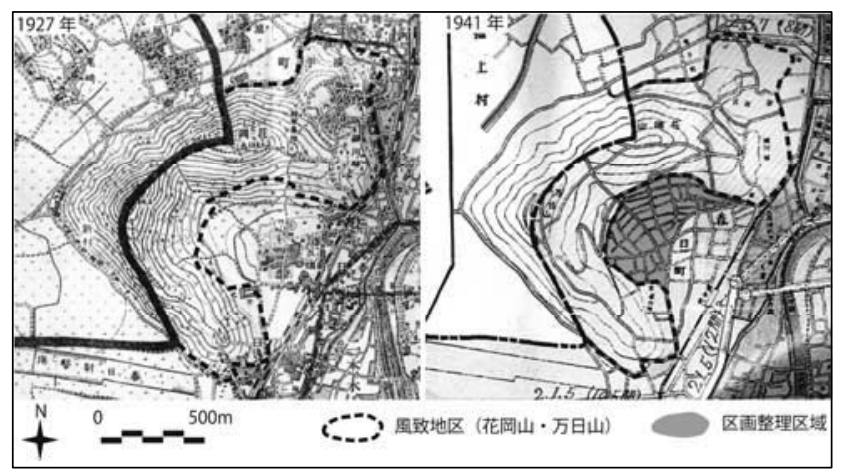

図-5 花岡山 · 万日山風致地区付近の区画整理 
実際に都市計画として区画整理事業が決定したのは、1937 年ま でに4か所あり、それは成趣園風致地区の周囲の国府 (1931 年)、 大江東部（1932 年)、水前寺（1932 年）の 3 箇所と、花岡山、万

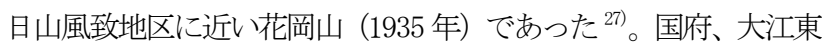
部、水前寺の 3 箇所は、街路計画策定の段階でも区画整理が予定 されていた場所である。また、4箇所の区画整理事業は、いずれ も風致地区の周囲であった。各区画整理事業の詳細な区域は資料 が無く分からないが、都市計画決定の区画整理組合の名称と面積、 および 1927 年と 1941 年の地形図の比較から、図 4、図 5 の通り 区画整理の範囲を推定した。これを見ると、区画整理事業組合は 4箇所であるが、国府 (1931 年)、大江東部 (1932 年)、水前寺 (1932 年) の3つは一連の区画整理であるといえる。これをひとつと見 な寸と、成趣園、江津湖風致地区付近と花岡山・万日山風致地区

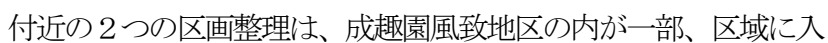
っているほか、いずれも風致地区に接していることがわかる。

また、区画整理以前の状態を見てみると、これらの風致地区は 密集市街地の整理ではなく、風致地区全体の説明にあったように、 市街化する前の土地を区画整理したものであることが分かる。

\section{（4）都市整備と風致地区の関係}

\section{以上より、つぎの 4 点がわかった。}

1) 画津村の合併の状況から、江津湖風致地区は単に風致を保存 するだけではなく、積極的に都市計画事業を行い熊本市民の ための郊外公園となるよう考えられていたことがわかった。

2）都市計画街路の計画の状況から、都心から比較的遠い八景水 谷、立田山、成趣園、江津湖の 4 風致地区は、熊本都市圈の 外一と向から意識がある方向に計画されたことが分かった。

3）すべての風致地区は街路計画や既存の交通網によって交通の 便が保証されているところに設置されたことがわかった。

4）土地区画整理事業の理由と場所から、郊外を適切に発展させ ていくために土地区画整理をしようとしていたこと、その場 所はいずれも風致地区に接していたことがわかった。

\section{4. 指定後における風致地区周辺の開発動向}

前章では都市全体の整備動向と風致地区との関係を見た。本章 では、各風致地区やその付近がどのように整備されていったのか を見ることによって、計画の段階では分からなかった都市形成の 意図を読み取ることとする。整備を見るにあたっては、もともと の風致地区の展望にあった公園化や住宅地化に着目する。

\section{（1）風致地区と公園化}

花岡山地区、江津湖地区、立田山地区では、それぞれ花岡山登 山道開檕期成会 (1932 年設立) ${ }^{28)}$ 、江津湖公園期成会 (1932 年設 立） ${ }^{29)}$ 、立田山期成会（1934 年設立） ${ }^{30 ）}$ という公園化を図る団体 が組織された。花岡山地区では、1933 年に北岡神社裏から春日陸 橋を通り招魂社にいたる自動車道路が開通した。「春日校創立百 周年記念春日の歴史」には「中腹まではりっぱな環状道路ができ て、花岡山もようやくサクラと史蹟の名所として面目を一新する に至った」と記されている ${ }^{31)}$ 。立田山地区では、1935 年に公園化 の最初の事業として、泰勝寺を起点として上水道配水池下を通過 し拝聖庵にいたる登山道が開通した。開通当日の新聞には「絶好 の眺望をもつ理想的登山道路」ができたことが記されている ${ }^{32)}$ 。 1933 年には、画津公園協会が江津湖公園期成会をとりこむかたち で設立された ${ }^{33)}$ 。これら江津湖における公園化を図る団体は、北 村徳太郎が 1931 年の「都市公論」で発表した「江津湖を中心とし たる公園計畫」を中心に据えていた。戦前において、江津湖湖地 区では本格的な公園化は実現されていないものの、浚渫や除草な どの美化活動、道路や橋梁の計画・整備、遊覧船の運航など、公 園化の実現へ向けた動きがあった ${ }^{34)}$-40)。また 1936 年には、内務 省衛生局より、県立公園候補地の指定も受けている。
八景水谷地区、本妙寺山地区については、公園化を図る団体は 組織されていない。しかし八景水谷は、公園的施設をつくるため、 1932 年に市役所によりすべて買収された ${ }^{41)}$

また、本妙寺山地区については、1933 年に本妙寺裏の市有地に 公営墓地が完成した。着工前の候補地視察に関寸る新聞記事には、 公営墓地の完成により「墓地難」の解消と「本妙寺を中心とした 公園化の一部完成」がみられることが記されている ${ }^{42}$ 。また、1934 年には熊本営林局により、本妙寺山腹に植物園が設置され、4月 2〜4 日の愛林デーに合せて一般に開放された ${ }^{43)}$ 。

\section{（2）風致地区と住宅地化}

前章でも触れたように、1937 年までに成趣園風致地区付近に国 府第一、水前寺、大江東部の 3 つ土地区画整理組合、花岡山、 万日山風致地区付近に花岡山土地区画整理組合がつくられ、都市 計画事業として土地区画整理が行われた。

水前寺土地区画整理については、1932 年 10 月の工事着手に関 する新聞記事に、土地が高燥で環境上からも住宅地として最も適 当な場所であり、付近には公設運動場や帯山練兵場、渡鹿練兵場 など、慰安、休養、運動施設もあるので、「絶好の住宅地になるで あらう」と記されて、環境の良い住宅地となることが期待されて いる ${ }^{44)}$ 。ただし、同記事では割地の予定として、住宅用は奥行 $20 \mathrm{~m}$ 、 間口 $13 \mathrm{~m}$ 、商店向きは奥行 $24 \mathrm{~m}$ 、間口 $8 \mathrm{~m}$ の予定とあり、区画整理 によってつくりだすのは、住宅地だけではなく、商業地も含んで いたことが分かる。実際、1928 年こ決定された用途地域では、も ともと商業地では無かった場所や風致地区内でも、街路予定地の 沿線に商業地域が指定されている (図6)。同時期に、成趣園の周 囲である市域南東部の、国府、大江東部でも区画整理が行われた。 1937 年 6 月の九州日日新聞には、そのあたりで方面において、著 しく地価が上昇していることが記載されている ${ }^{45)}$

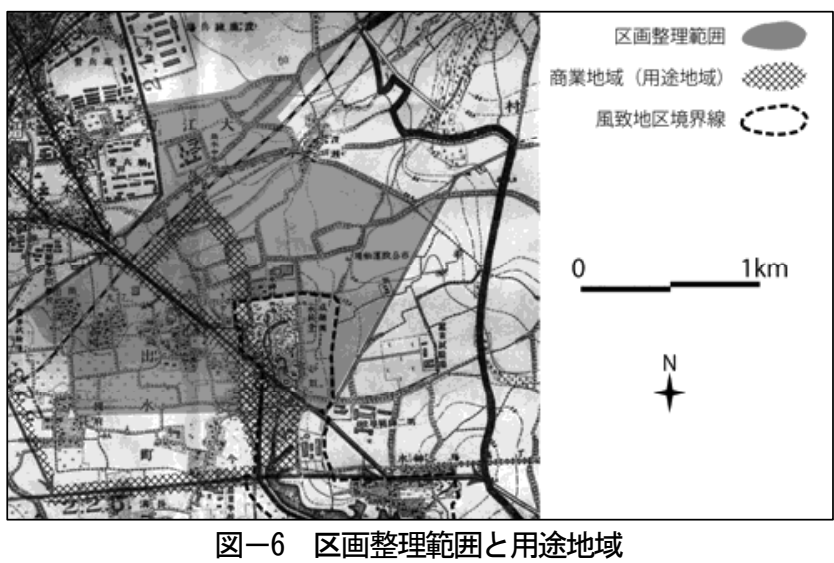

花岡山土地区画整理では、平坦地と段々畑であった花岡山・万 日山の中腹までの地域が区画整理された（図 5)。

「春日校創立百周年記念 春日の歴史」によると、花岡山土地 区画整理組合設立の背景には、花岡山地区が熊本駅から至近距離 の非常に便利な位置にあるにもかかわらず、はす池などの沼沢が 介在していたため、宅地の利用に適せず放置されていたとある ${ }^{46)}$

1937 年 3 月に行われた起工式では、花岡山土地区画整理組合長 が「由來花岡山及附近一帶の地たるや方に熊本市の表立關とも言 ふ心゙く殊に風光明媚最も住宅地に適し大公園たる地相素質を完具 し」と述べている ${ }^{47)}$ 。また起工式3 日前の新聞によると、実現の 暁には花岡山の公園化を促し、住宅地、市街地としての地方開発 と将来の繁栄が期待されていた ${ }^{48)}$ ということである。1935 年4 月の新聞では、施工地域について「風致地區花岡山松山の南麓一 帶を占むる景勝絶佳の地」と紹介された ${ }^{49)}$ 。

この区画整理対象地は、用途地域でも住宅地に設定されており、 実際に住宅地として整備された。花岡山、万日山などの風致地区 
の風光を意識した住宅地であったことが分かる。

\section{5. 熊本の都市形成における風致地区の位置付け}

本研究では、戦前熊本における風致地区は、都市形成において どのような位置付けにあったのかを明らかにした。

すでに公園として利用されていた成趣園を含む全ての風致地区 には、公園として利用され熊本市民の保健に資するという期待が あった。そのために、風致を保存するだけでなく、人が訪れるた めの施設整備を予定していた。都市形成との関連を見ても、江津 湖風致地区は、公園のための施設整備をするために画津村の合併 が行われたことが分かった。交通網との関係を見てみると、比較 的郊外にあった八景水谷、立田山、成趣園、江津湖風致地区は、

都心から延びる放射状街路の付近に計画され、その他の3つの風 致地区はもともと市街地に接しており、交通の便も寸でに良い地 域であり、市民がそこに行くことが重視された風致地区であった ことがここからも確認できた。

郊外に計画された八景水谷、立田山、成趣園、江津湖の 4 風致 地区は、熊本市街地の周縁部というだけでなく、都市計画区域外 につながることが期待されていた街路付近に計画された。なかで も、南方面の成趣園、江津湖風致地区方面に延びる街路は、土地 区画整理の基淮となるように考えられており、成趣園、江津湖風 致地区方面は、市街地が発展寸る方向であると考えられていた。 実際、風致地区の内部やそこに接する土地で区画整理事業が行わ れた。新聞などでは、良好な住宅地となると報道されたが、開発 されていなかった風致地区の一部も含むように商業地に指定され るなど、住宅地だけというわけではなく、通常の市街化であった といえる。一方、花岡山、万曰山に囲まれるような場所で行われ た区画整理では、住宅地が形成された。

以上より、熊本の都市形成における風致地区は、市民の為の郊 外の公園という位置付けが大きかったことが分かった。また、一 部の風致地区では、その良好な環境を享受できる良好な住宅地の 開発といら期待もあり、合併時の挨拶、新聞記事などでも同样の 認識が見られた。しかし実際に風致地区内部や付近で行われた区 画整理事業は、必ずしも住宅地ではなく、郊外の良好な環境を住 環境として享受するイメージと実際の整備は、成趣園周辺では一 致していなかったことも明らかとなった。

今後、熊本以外の都市計画区域についても風致地区と都市形成 の関係を明らかにすることで、戦前期の風致地区の都市形成上の 役割を明らかにしていくことができると考えられる。

\section{補注及び引用文献}

1）北村徳太郎(1931）: 熊本市郊外江津湖を中心とする敷地計畫殊に其の公園系 統に就て : 都市公論 $16(2), 8-25$

2) 都市計画熊本地方委員会 (2001) : 熊本都市計画参考資料 第 4 集 : 熊本市 史関係資料集第 5 集, $182-236$

3）佐藤昌(1977):日本公園緑地発達史上 : 473-477, 都市計画研究所

4）種田守孝ら(1989）: 戦前期における風致地区の概念に関寸る研究 : 造園杂隹誌 59(5), 300-305

5）原泰之ら(2006) : 戦前期における風致地区制度の位置付けに関する歴史的考 察: ランドスケープ研究 69(5), 813-816

6) 皆方訓久(1997) : 戦前の風致地区における風致保全の実態とその評価 : ラン ドスケープ研究 60(5), 451-454

7) 中林浩(1982)：1930 年代における景観・都市美についての計画理念：日本都 市計画学会学術研究発表会論文集 $17,433-438$

8）福島二朗ら(2006) : 昭和初期における足利都市計画風致地区の設定過程につ いての一考察 : 土木史研究溝演集 26, 257-265

9）阿部伸太(1993）: 都市の公園緑地計画における風致地区の意義 : 造園雑誌 56(5), 313-318

10) 本田百合絵ら(2009) : 近代熊本都市計画における江津湖の位置付けに関寸る 一考察 : 土木史研究論文集 $28,123-130$

11）野中勝利(1995) : 城下町都市における戦前の風致地区の指定にみる都市づく
り上の風致地区の位置づけと役割 : 日本建築学会計画系論文集 471，99-109 12）都市計畫熊本地方委員会 (1930) : 熊本都市計画風致地区決定ノ件 : 公文雑 纂昭和五年第三十巻都市計画五

13）都市計画熊本地方委員会（1999）: 第五回都市計画熊本地方委員会会議録： 新熊本市史編箱委員会『新熊本市史 史料編第七巻近代II』: 熊本市, $309 \mathrm{pp}$ 14) 前掲 2), $229 \mathrm{pp}$

15) 熊本市役所観光倸(1937) : 景勝の熊本 : 熊本観光協会, 22-23

16) (1999) : 飽託郡画四村合併一件市政資料 2090 : 新熊本市史編箘委員会『新 熊本市史 史料編第七巻近代II : 熊本市, $128-129$

17) 都市計畫熊本地方委員会 (1925) : 熊本都市計画熊本地方委員会会議録第2 回, $16-25$

18) 前掲 16), $128 \mathrm{pp}$

19）前掲 16), $129 \mathrm{pp}$

20) 前掲 16), $129 \mathrm{pp}$

21）前揭 16)， $129 \mathrm{pp}$

22）九州日日新聞社 (1939), 「けふから熊本市民となる清水村民の喜び—盛大な 合併祝賀會一」, 九州日日新聞, 昭和 14 年 8 月 1 日

23）都市計画熊本地方委員会 (1999)，「第三回都市計画熊本地方委員会会議録」, 新熊本市史編篹委員会『新熊本市史 史料編第七巻近代II』, pp.263-292, 熊本市

24) 前掲 23)， $279 \mathrm{pp}$

25) 前掲 23) , $282 \mathrm{pp}$

26) 前掲 23)， $272 \mathrm{pp}$

27) 熊本市役所土木課 (1939) : 熊本都市計畫概要 : 熊本市, 6-7

28）九州日日新聞社 (1932)：花岡山南側自動車登山道路一期成会を組織して目 的の達成を期す一: 九州日日新聞, 昭和 7 年 10 月 21 日

29）九州日日新聞社 (1932) : 時機と人の和を得て画因湖公園期成会きのふ盛大 に発会式: 九州日日新聞, 昭和 7 年 6 月 19 日

30) 九州日日新聞社 (1934) : 熊本市に新名所一つ立田山の公園化: 九州日日新 聞, 昭和 9 年 10 月 5 日

31) 熊本市役所 (1932) : 熊本市史 : 熊本市, 909-910

32) 九州日日新聞社 (1935) : 立田山登山道けふ開通式: 九州日日新聞, 昭和 10 年 11 月 5 日

33）九州日日新聞社 (1933) : 画津公園協会いよいよ組織に決定:九州日日新聞, 昭和 8 年 6 月 11 日

34) 熊本市春日小学校 (1973) : 春日校創立百周年記念 春日の歴史 : 創立百周 年記念事業期成会, $40 \mathrm{pp}$

35）九州日日新聞社 (1934) : 畫津湖中嶋を市が拂下げ希望—將來の公園施設に - : 九州日日新聞, 昭和 9 年 6 月 23 日

36）九州日日新聞社（1935）: 畫津湖公園化の計畫すつむ一湖心の中之島に遊園 地的施設が出來る : 九州日日新聞, 昭和 10 年 6 月 1 日

37）九州日日新聞社（1935）: 畫津の新橋ば”畫津橋”と命名公園化促進に一層努 力: 九州日日新聞, 昭和 10 年 6 月 5 日

38) 九州日日新聞社 (1934) : 明春三月迄に畫津湖の美化 : 九州日日新聞, 昭和 9 年 10 月 23 日

39）九州日日新聞社 (1935) : 水前寺から畫津湖一出る遊覧船が出來た : 九州日 日新聞, 昭和 10 年 4 月 12 日

40）九州日日新聞社（1935）：下畫圖道路と中島を繫く架橋一嶋内休憩所や大型 船新造明年度あたり實現一 : 九州日日新聞，昭和 10 年 9 月 6 日

41）九州日日新聞社 (1932) : 公園的施設の八景水谷一本年は蛍が多し: 九州 日日新聞，昭和 7 年 5 月 31 日

42）九州日日新聞社（1932）：公營墓地の候補地視察一本妙寺を中心とした公園 化も一部完成一 : 九州日日新聞, 昭和 7 年 9 月 1 日

43）九州日日新聞社（1934）: 本妙寺山腹に大植物園を設置 : 九州日日新聞, 昭 和 9 年 3 月 29 日

44) 九州日日新聞社（1932）: 水前寺區劃整理愈上工事着手：九州日日新聞，昭 和 7 年 10 月 5 日

45) 九州日日新聞社 (1937) : 熊本市の一等地は新市街世界館附近 : 九州日日新 聞, 昭和 12 年 6 月 30 日

46) 熊本市春日小学校 (1973) : 春日校創立百周年記念 春日の歴史 : 創立百周 年記念事業期成会, $28 \mathrm{pp}$

47) 九州日日新聞社 (1937) : 市南部地方開發一花岡山區整起工式きのふ盛大に 舉行一: 九州日日新聞, 昭和 12 年 4 月 1 日

48) 九州日日新聞社 (1937) : 花岡山區整第一期工事一三十一日起工式一 : 九州 日日新聞, 昭和 12 年 3 月 28 日

49）九州日日新聞社（1935）: 花岡山の南麓一帶の區劃整理三ヶ年繼續實施一完 成後の大繁榮期待さる一 : 九州日日新聞, 昭和 10 年 4 月 10 日 